\title{
In Focus
Spotlight on the November 7 issue
}

Robert A. Gross, MD, PhD, FAAN

Editor-in-Chief, Neurology ${ }^{\circledR}$

\section{Notable in Neurology}

This issue features an article that examines changes in CSF biomarkers and the relationship to clinical measures in patients with Parkinson disease and healthy controls, and another that determines a correlation between home-time and modified Rankin Scale scores. A featured article clarifies the prevalence of neuromyelitis optica spectrum disorders in Japan.

\section{ARTICLES}

\section{Longitudinal decline of driving safety in Parkinson disease $\mathbb{D}$.}

This study assessed the change in driving ability of patients with Parkinson disease (PD). Drivers with PD were at risk for significant deterioration within a relatively short period. The driving skills and underlying cognitive, visual, and motor abilities of patients with PD should be monitored.

See p. 1951

\section{Increasing prevalence of vascular risk factors in patients with stroke: A call to action}

Using the 2004-2014 National Inpatient Sample, the authors describe recent trends in the prevalence of cardiovascular risk factors and diseases in patients with stroke. The proportion of patients with stroke and single or multiple vascular risk factors increased significantly in all patient groups over the last decade.

\section{See p. 1985}

From editorialist Prabhakaran: "While there should indeed be a call to action to prevent stroke and its negative consequences on society, we should acknowledge important progress that has been made in stroke prevention, even if there is much more work to be done."

See p. 1940

\section{Subjective cognitive decline and $\beta$-amyloid burden predict cognitive change in healthy elderly}

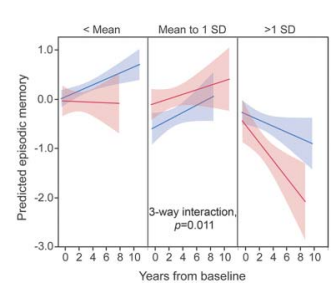

Subjective cognitive decline (SCD)

is a common symptom among older people that may predict substantial objective cognitive decline. In this study, individuals with evidence for both brain $\beta$-amyloid and considerable SCD showed significant cognitive decline over a 4-year average, while individuals with only $\beta$-amyloid showed little evidence of decline.

See p. 2002

\section{Effect of concussion and blast exposure on symptoms after military deployment}

The authors examined whether blast exposure and blastassociated concussion result in similar clinical sequelae using a questionnaire administered to US Marines. Compared to blast exposure without injury, concussion during deployment or being moved or injured by a blast had increased risk of postinjury symptoms. Concussion had the greatest influence on the presence of symptoms.

See p. 2010

NB: "Ping-pong gaze and ocular nodding in bacterial meningitis," p. 2021. To check out other Video Neurolmages, point your browser to Neurology.org. At the end of the issue, check out the Resident \& Fellow Teaching Neurolmage discussing taste loss in the anterior tongue due to Bell palsy and another on vision loss after head trauma due to fibrous dysplasia. This week also includes a Clinical/Scientific note titled "Anti-cytosolic 5'-nucleotidase 1A (cN1A) autoantibodies in motor neuron diseases." 


\title{
Neurology
}

\author{
Spotlight on the November 7 issue \\ Robert A. Gross \\ Neurology 2017;89;1933 \\ DOI 10.1212/WNL.0000000000004619
}

This information is current as of November 6, 2017

$\begin{array}{ll}\begin{array}{l}\text { Updated Information \& } \\ \text { Services }\end{array} & \begin{array}{l}\text { including high resolution figures, can be found at: } \\ \text { http://n.neurology.org/content/89/19/1933.full }\end{array} \\ \text { Permissions \& Licensing } & \begin{array}{l}\text { Information about reproducing this article in parts (figures,tables) or in } \\ \text { its entirety can be found online at: } \\ \text { http://www.neurology.org/about/about_the_journal\#permissions }\end{array} \\ \text { Reprints } & \begin{array}{l}\text { Information about ordering reprints can be found online: } \\ \text { http://n.neurology.org/subscribers/advertise }\end{array}\end{array}$

Neurology ${ }^{\circledR}$ is the official journal of the American Academy of Neurology. Published continuously since 1951, it is now a weekly with 48 issues per year. Copyright () 2017 American Academy of Neurology. All rights reserved. Print ISSN: 0028-3878. Online ISSN: 1526-632X.

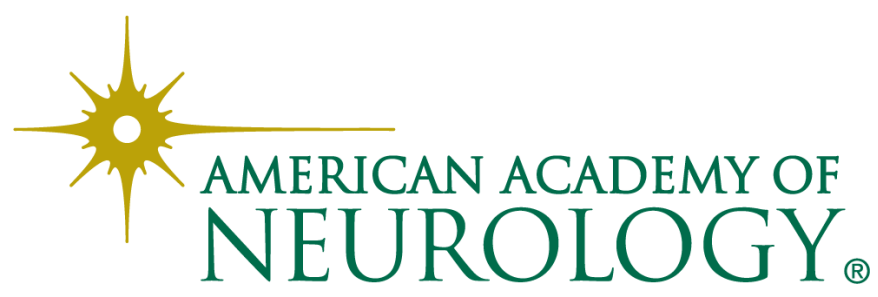

